\title{
Vitamin D-Binding Protein
}

National Cancer Institute

\section{Source}

National Cancer Institute. Vitamin D-Binding Protein. NCI Thesaurus. Code C84254.

Vitamin D-binding protein (474 aa, $\sim 53 \mathrm{kDa}$ ) is encoded by the human GC gene. This protein plays a role in both vitamin transport and actin polymerization. 